\title{
Robustness and Ethanol Production of Industrial Strains of Saccharomyces cerevisiae Using Different Sugarcane Bagasse Hydrolysates
}

\author{
Vanessa S. Teixeira \\ Department of Food Engineering, University of Campinas \\ Monteiro Lobato Street, 80, Campinas, SP, ZIP Code 13083-862, Brazil \\ Suéllen P. H. Azambuja \\ Department of Food Engineering, University of Campinas \\ Monteiro Lobato Street, 80, Campinas, SP, ZIP Code 13083-862, Brazil \\ Priscila H. Carvalho \\ Department of Food Engineering, University of Campinas \\ Monteiro Lobato Street, 80, Campinas, SP, ZIP Code 13083-862, Brazil
}

Fátima A. A. Costa

Department of Food Engineering, University of Campinas

Monteiro Lobato Street, 80, Campinas, SP, ZIP Code 13083-862, Brazil

\section{Patricia R. Kitaka}

Pluridisciplinary Center for Chemical, Biological and Agricultural Research (CPQBA), University of Campinas

Alexandre Cazelatto Street, 999, Vila Betel, Paulínia, SP, ZIP Code 13148-218, Brazil 


\title{
Claudia Steckelberg
}

Pluridisciplinary Center for Chemical, Biological and Agricultural Research (CPQBA), University of Campinas

Alexandre Cazelatto Street, 999, Vila Betel, Paulínia, SP, ZIP Code 13148-218, Brazil

\section{Silvio R. Andrietta}

Pluridisciplinary Center for Chemical, Biological and Agricultural Research (CPQBA), University of Campinas

Alexandre Cazelatto Street, 999, Vila Betel, Paulínia, SP, ZIP Code 13148-218, Brazil

\section{Maria G. S. Andrietta}

Pluridisciplinary Center for Chemical, Biological and Agricultural Research (CPQBA), University of Campinas

Alexandre Cazelatto Street, 999, Vila Betel, Paulínia, SP, ZIP Code 13148-218, Brazil

\author{
Rosana Goldbeck (Corresponding author) \\ Department of Food Engineering, University of Campinas \\ Monteiro Lobato Street, 80, Campinas, SP, ZIP Code: 13083-862, Brazil \\ Tel: +551935214038Ｅ-mail: rosana.goldbeck@gmail.com \\ https://orcid.org/0000-0003-2953-8050
}

Received: April 1, 2019 Accepted: May 5, $2019 \quad$ Published: May 7, 2019

Doi: 10.5296/jab.v7i1.14599 URL: https://doi.org/10.5296/jab.v7i1.14599

\begin{abstract}
Sugarcane bagasse is one of the main lignocellulosic raw materials used for the production of second-generation ethanol. Technological studies on fermentation processes have focused on the search for and development of more robust microorganisms that are able to produce bioethanol efficiently and are resistant to the main fermentation inhibitors. The purpose of this study was to evaluate the robustness and ethanol production of industrial strains of Saccharomyces cerevisiae using acid, alkaline, and enzymatic sugarcane bagasse hydrolysates. Hydrolysis was carried out to release fermentable sugars from sugarcane
\end{abstract}


bagasse. Fermentations were performed in shake flasks containing sugarcane hydrolysates supplemented with $150 \mathrm{~g} \mathrm{~L}^{-1}$ glucose to evaluate the kinetic parameters of the reaction. Inhibitor tolerance was evaluated by incubating cells with different concentrations of inhibitors in 96-well plates. The biomass yield on substrate, ethanol yield on substrate, and ethanol productivity of the six strains were higher in $0.5 \%$ acid, $0.5 \%$ alkaline, and enzymatic hydrolysates (i.e., under milder conditions). The SA-1 (Santa Adélia-1) strain had a better performance in comparison with the other strains for its ability to produce ethanol in a very severe condition (7\% acid hydrolysis) and for its robustness in growing at several inhibitor concentrations.

Keywords: S. cerevisiae, Sugarcane hydrolysates, Robustness, Bioethanol, Inhibitors tolerance

\section{Introduction}

Brazil stands out in the world production of ethanol from sugarcane, generating abundant amounts of residues made of cellulose, hemicellulose, and lignin that can be used as raw material for the production of second-generation ethanol and other high value-added products of industrial interest (Balat, 2011). Sugarcane bagasse is one of the main lignocellulosic raw materials used for the production of second-generation ethanol. Each tonne of pressed sugarcane produces, on average, $250 \mathrm{~kg}$ of bagasse with around $50 \%$ moisture (Martín et al., 2006). Its constituent polymers are cellulose (40-45\%), hemicellulose (30-35\%), and lignin (20-30\%); and its main sugars, glucose (43\%) and xylose (24-32\%). The amount of each constituent may vary depending on pretreatment and hydrolysis methods (Peng et al., 2009).

Production of bioethanol from lignocellulosic biomass consists of three main steps: pretreatment of the lignocellulosic biomass, cellulose saccharification, and glucose fermentation. Thermal, chemical, or enzymatic processes may be employed as pretreatment. Thermal pretreatment involves the use of high temperature, and, as a consequence, fermentation inhibitors are formed, such as furfural, formed from the degradation of pentoses (xylose and arabinose); 5-hydroxymethylfurfural (HMF), formed by the degradation of hexoses (glucose, mannose, and galactose); formic acid, a result of the degradation of HMF; phenolic compounds, generated from the degradation of lignin; and acetic acid, formed by deacetylation of hemicellulose. These compounds, when present in the culture medium, can damage the cell wall of microorganisms, reduce the absorption of aromatic amino acids from the medium, inhibit enzymes (alcohol dehydrogenase, pyruvate dehydrogenase, and aldehyde dehydrogenase), and prolong the lag phase (Almeida et al., 2007; Cheng et al., 2008; Yang et al., 2010). Chemical hydrolysis is a good option for industrial-scale processing of biomass, but process conditions promote the generation of by-products that significantly inhibit fermentation (Balat, 2011). On the other hand, enzymatic depolymerization, which can be performed with different enzymes, such as endoglucanases, exoglucanases, and $\beta$-glucosidases, favors the selective conversion of cellulose to glucose and is favorable in an industrial scale, but this process is expensive and requires large amounts of enzymes and greater control of process conditions (Bastos, 2007).

In recent years, technological studies on fermentation processes have focused on the search 
for and development of more robust microorganisms that are able to produce bioethanol efficiently and are resistant to the main fermentation inhibitors (Almeida et al., 2009; Pereira et al., 2014). The strain must be tolerant to the industrial stresses and inhibitors present in the process, so that they may be able to produce ethanol from hydrolysates supplemented with molasses. Industrial strains of Saccharomyces cerevisiae show robustness and good fermentative capacity (Mussatto et al., 2010) under the conditions to which they are exposed, such as high sugar concentration, high temperatures, large $\mathrm{pH}$ variations, and high concentrations of toxic compounds (Della-Bianca et al., 2013). Thus, the microflora of traditional and industrial fermentation processes is a good source of microbial isolates that naturally exhibit the desired characteristics for the fermentation of lignocellulosic materials. Moreover, some laboratory strains of $S$. cerevisiae express flocculent character under environmental stress conditions. This characteristic may be useful for lignocellulosic ethanol production since flocculant strains have already been used commercially in brewing and flocculent yeasts can be more easily separated from the fermentation medium, thus reducing the cost of the process (Landaeta et al., 2013). Although $S$. cerevisiae are potential candidates that can resist the stressful conditions imposed on yeast cells in lignocellulosic fermentation processes and thus represent an alternative to further develop this technology, the use and characterization of these isolates in lignocellulosic fermentations have not yet been reported (Pereira et al., 2014).

In this context, this study aims to evaluate the bioethanol production capacity and robustness of six industrial strains of $S$. cerevisiae using sugarcane bagasse hydrolyzed by three methods (acid, alkaline, and enzymatic hydrolyses). Hydrolysates were characterized according to the concentration of inhibitors (furfural, HMF, and acetic acid). Fermentation performance was evaluated from the kinetic parameters biomass yield on substrate $\left(\mathrm{Y}_{\mathrm{X} / \mathrm{S}}\right)$, and ethanol yield on substrate $\left(\mathrm{Y}_{\mathrm{P} / \mathrm{S}}\right)$. Fermentation efficiency was evaluated from the relationship between $\mathrm{Y}_{\mathrm{P} / \mathrm{S}}$ and the maximum theoretical fermentation yield.

\section{Material and Methods}

\subsection{Yeast Strains}

Six industrial strains of $S$. cerevisiae isolated from regional sugarcane mills were studied: CAT-1 (Catanduva), PE-2 (Pedra), FT858 (Fermentec), SM (São Manoel), SA-1 (Santa Adélia), and NAD (Nardini). Yeast cells were maintained in YEPD solid medium $\left(10 \mathrm{~g} \mathrm{~L}^{-1}\right.$ yeast extract, $20 \mathrm{~g} \mathrm{~L}^{-1}$ peptone, $20 \mathrm{~g} \mathrm{~L}^{-1}$ glucose, and $20 \mathrm{~g} \mathrm{~L}^{-1}$ agar). The strains were included in the industrial yeast collection of the Bioprocess Division of CPQBA (Chemical, Biological and Agricultural Pluridisciplinary Research Center, Campinas, SP, Brazil).

\subsection{Hydrolysis of Sugarcane Bagasse}

Hydrolysis was carried out using sugarcane bagasse pretreated by steam explosion, provided by the Nardini Ethanol Plant (Vista Alegre do Alto, SP, Brazil), previously dried at $105^{\circ} \mathrm{C}$ for $24 \mathrm{~h}$ and with a solid concentration of $5(\mathrm{w} / \mathrm{v})$. Five different types of hydrolysis treatments were chosen to be evaluated: two acid hydrolyses (concentrated acid hydrolysis, using 7\% $\mathrm{H}_{2} \mathrm{SO}_{4}$, and dilute acid hydrolysis, using $0.5 \% \mathrm{H}_{2} \mathrm{SO}_{4}$, at $121{ }^{\circ} \mathrm{C}$ and 1 atm for $30 \mathrm{~min}$, in 
autoclave), two alkaline hydrolyses (concentrated alkaline hydrolysis, using $7 \% \mathrm{NaOH}$, and dilute alkaline hydrolysis, using $0.5 \% \mathrm{NaOH}$, at $121{ }^{\circ} \mathrm{C}$ and 1 atm for $30 \mathrm{~min}$, in autoclave), and an enzymatic hydrolysis using $100 \mu \mathrm{L}$ of the commercial enzymatic cocktail Accellerase (DuPont, USA) per gram of bagasse in $100 \mathrm{mM}$ acetate buffer, $\mathrm{pH} 5$, at $50{ }^{\circ} \mathrm{C}$ for $24 \mathrm{~h}$.

The concentration of reducing sugars (RS) present in the hydrolysates was determined by the DNS (3,5-dinitrosalicyclic acid) method according to the methodology described by Miller (1959).

\subsection{Fermentation of Hydrolysates}

The inoculum was prepared by placing yeast cells from the solid medium into a $250 \mathrm{~mL}$ shake flask containing $100 \mathrm{~mL}$ of YEPD medium $\left(10 \mathrm{~g} \mathrm{~L}^{-1}\right.$ yeast extract, $20 \mathrm{~g} \mathrm{~L}^{-1}$ peptone, and $20 \mathrm{~g} \mathrm{~L}^{-1}$ glucose) and cultivating them at $30^{\circ} \mathrm{C}$ and $150 \mathrm{rpm}$ for $24 \mathrm{~h}$. Fermentations were carried out in shake flasks $(250 \mathrm{~mL}$ Erlenmeyer flasks) using sugarcane bagasse hydrolysates as substrate (concentrated (7\%) and dilute (0.5\%) acid hydrolysates, concentrated $(7 \%)$ and dilute $(0.5 \%)$ alkaline hydrolysates, and enzymatic hydrolysates, separately). Media were supplemented with glucose up to $150 \mathrm{~g} \mathrm{~L}^{-1}$ (based on the concentration of RS) and adjusted to $\mathrm{pH} 5.0$. For the fermentation, $90 \mathrm{~mL}$ of bagasse hydrolysate and $10 \mathrm{~mL}$ of inoculum were cultivated at $30{ }^{\circ} \mathrm{C}$ and $150 \mathrm{rpm}$ for $48 \mathrm{~h}$. All fermentation experiments were carried out in duplicate. Sample collection was performed at pre-determined times: $0,12,24,36$, and 48 h of fermentation. Samples were then centrifuged for $10 \mathrm{~min}$ at $10,000 \times \mathrm{g}$ and subjected to analytical determinations.

\subsection{Analytical Methods}

Glucose and ethanol concentrations were quantified using an HPLC (Varian, Inc., USA) equipment with an RI detector (RI 2000, Chrom Tech Inc., Germany) and an Aminex HPX-87H ion-exchange column (BioRad, USA) at $30{ }^{\circ} \mathrm{C}$ with $5 \mathrm{mM} \mathrm{H}_{2} \mathrm{SO}_{4}$ as mobile phase

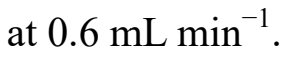

Furfural and HMF concentrations were quantified by HPLC (Thermo Fischer Scientific, USA) using a PDA detector (Thermo Fischer Scientific, USA) and a Hypersil Gold C18 column (Thermo Fischer Scientific, USA) at $25^{\circ} \mathrm{C}, 280 \mathrm{~nm}$. As mobile phase, 1:8 acetonitrile/water with $1 \%$ acetic acid solution was used at $0.3 \mathrm{~mL} \mathrm{~min}^{-1}$. Acetic acid was detected using a HyperREZ XP column (Thermo Fischer Scientific, USA) at $35{ }^{\circ} \mathrm{C}$ with $5 \mathrm{mM} \mathrm{H}_{2} \mathrm{SO}_{4}$ as mobile phase at $0.6 \mathrm{~mL} \mathrm{~min}^{-1}$.

Biomass concentration was determined gravimetrically by drying the samples in an air-circulating oven at $60{ }^{\circ} \mathrm{C}$ until constant weight (Charoenchai et al., 1998) with modifications.

\subsection{Determination of Kinetic Parameters}

The biomass yield on substrate $\left(\mathrm{Y}_{\mathrm{X} / \mathrm{S}}\right)$, $\mathrm{g}$ biomass $\mathrm{g}^{-1}$ substrate), ethanol yield on substrate $\left(\mathrm{Y}_{\mathrm{P} / \mathrm{S}}\right)$, g ethanol $\mathrm{g}^{-1}$ substrate), and ethanol productivity $\left(\mathrm{P}_{\mathrm{P}}, \mathrm{g} \mathrm{L}^{-1} \mathrm{~h}^{-1}\right)$ were calculated using the following equations: 


$$
\begin{gathered}
Y_{X / S}=\frac{X_{\mathrm{f}}-X_{0}}{S_{0}-S_{\mathrm{f}}} \\
Y_{P / S}=\frac{\text { ethanol }_{\mathrm{f}}}{S_{0}-S_{\mathrm{f}}} \\
P_{P}=\frac{\text { ethanol }_{\mathrm{f}}}{t_{\text {fermentation }}}
\end{gathered}
$$

where $\mathrm{X}_{\mathrm{f}}$ is the final biomass concentration $\left(\mathrm{g} \mathrm{L}^{-1}\right), \mathrm{X}_{0}$ is the initial biomass concentration ( $\mathrm{g}$ $\left.\mathrm{L}^{-1}\right), \mathrm{S}_{0}$ is the initial glucose concentration $\left(\mathrm{g} \mathrm{L}^{-1}\right), \mathrm{S}_{\mathrm{f}}$ is the final glucose concentration $(\mathrm{g}$ $\left.\mathrm{L}^{-1}\right)$, ethanol $\mathrm{f}_{\mathrm{f}}$ is the final ethanol concentration $\left(\mathrm{g} \mathrm{L}^{-1}\right)$, and $\mathrm{t}_{\text {fermentation }}$ is the fermentation time (h).

\subsection{Inhibitor Tolerance}

Strains were grown in synthetic medium (Verduyn et al., 1992) with modifications: $3.0 \mathrm{~g} \mathrm{~L}^{-1}$ $\mathrm{KH}_{2} \mathrm{PO}_{4}, 6.6 \mathrm{~g} \mathrm{~L}^{-1} \mathrm{~K}_{2} \mathrm{SO}_{4}, 0.5 \mathrm{~g} \mathrm{~L}^{-1} \mathrm{MgSO}_{4} \cdot 7 \mathrm{H}_{2} \mathrm{O}, 2.3 \mathrm{~g} \mathrm{~L}^{-1} \mathrm{NH}_{2} \mathrm{CONH}_{2}$, and $20 \mathrm{~g} \mathrm{~L}^{-1}$ glucose at $30{ }^{\circ} \mathrm{C}$ and $200 \mathrm{rpm}$ for $24 \mathrm{~h}$. Cells from the inoculum were centrifuged at $5000 \times \mathrm{g}$ for $5 \mathrm{~min}$ and washed twice with fresh medium. The cell suspension was standardized to start the growth kinetics experiment with an initial $\mathrm{OD}_{600}$ between 0.1 and 0.2 . Cells were inoculated into fresh medium ( $20 \mathrm{~g} \mathrm{~L}^{-1}$ glucose) containing different concentrations of HMF $(1,2$, or $4 \%, v / v)$, furfural $(1,2$, or $4 \%, v / v)$, or acetic acid $(3,6$, or $12 \%, v / v)$. Cultivations were performed in 96-well plates sealed with PCR sealing films (UC-500 ultra-clear pressure sensitive sealing film, E\&K Scientific, Santa Clara, CA) and incubated at $30^{\circ} \mathrm{C}$ and $198 \mathrm{rpm}$ for $24 \mathrm{~h}$. Readings were taken on an Infinite ${ }^{\circledR}$ M200 96-well plate reader (Tecan, Männedorf, Switzerland). $\mathrm{OD}_{600}$ measurement of each well was performed every $30 \mathrm{~min}$. The maximum specific growth rate $\left(\mu_{\max }, \mathrm{h}^{-1}\right)$ was obtained by linear regression of the plot $\ln \mathrm{OD}_{600}$ versus time (h), and it corresponds to the slope of the linear region of the growth curve in the exponential phase. Then, the relative growth $\left(\mathrm{RG}^{\circ}\right)$ of the cultivations was determined using the $\mu_{\max }$ of cultivations with inhibitors and without inhibitors.

$$
\mathrm{RG} \%=\frac{\mu_{\max } \text { with inhibitor }}{\mu_{\max } \text { without inhibitor }} \times 100
$$

\subsection{Statistical Analysis}

Statistica ${ }^{\circledR} 5.5$ (Statsoft, USA) software was used to calculate the analysis of variance (ANOVA). The Tukey test was used to determine differences between samples using a significance level of $5 \%$.

\section{Results and Discussion}

\subsection{Hydrolysate Characterization}

Acid, alkaline, and enzymatic hydrolysates were characterized according to the concentration 
of reducing sugar and the inhibitors HMF, furfural, and acetic acid (Table 1).

Among the different hydrolysates, $0.5 \%$ acid treatment was able to release more sugars (14.48 $\mathrm{g} \mathrm{L}^{-1}$ ), being statistically different from the others. On the other hand, the $7 \%$ alkaline treatment released the lowest concentration of reducing sugars, being $1.70 \mathrm{~g} \mathrm{~L}^{-1}$. The objective of this study was to evaluate the robustness of different strains of S. cerevisiae against the inhibitors present in the hydrolysates, so that the amount of sugars present is not a variable of the process, thus allowing future comparison of yields, the hydrolysates were adjusted to a final concentration of $150 \mathrm{~g} \mathrm{~L}^{-1}$ glucose.

The 7\% acid hydrolysate presented the highest concentrations of HMF and furfural, being significantly different from the other hydrolysates. The use of acid makes the formation of furfural and HMF more probable in the hydrolysis of lignocellulosic materials. In addition, furfural concentration increases with acid concentration (Pattra et al., 2008; Cardona et al., 2010), as observed in this study, in which the concentration of furfural in $7 \%$ acid hydrolysate $\left(0.10 \mathrm{~g} \mathrm{~L}^{-1}\right)$ was ten times that of $0.5 \%$ acid hydrolysate $\left(0.01 \mathrm{~g} \mathrm{~L}^{-1}\right)$. In a study by Pattra et al. (2008), the authors evaluated the acid/furfural ratio in the acid hydrolysis of sugarcane bagasse without pretreatment and identified increasing concentrations of furfural $(0.12-1.30 \mathrm{~g}$ $\left.\mathrm{L}^{-1}\right)$ as $\mathrm{H}_{2} \mathrm{SO}_{4}$ concentration increased $(0.25-7.0 \%)$. The same pattern was observed for $\mathrm{NaOH}$ and HMF and furfural concentrations: the concentration of these inhibitors increased with the concentration of $\mathrm{NaOH}$ in alkaline hydrolyses (Table 1).

Table 1. Inhibitor (HMF, furfural, and acetic acid) concentrations in hydrolysates

\begin{tabular}{lllll}
\hline Hydrolysates & $\begin{array}{l}\text { Reducing } \\
\text { Sugars } \\
\left(\mathrm{g} \mathrm{L}^{-1}\right)\end{array}$ & $\begin{array}{l}\text { HMF } \\
\left(\mathrm{g} \mathrm{L}^{-1}\right)\end{array}$ & $\begin{array}{l}\text { Furfural } \\
\left(\mathrm{g} \mathrm{L}^{-1}\right)\end{array}$ & $\begin{array}{l}\text { Acetic Acid } \\
\left(\mathrm{g} \mathrm{L}^{-1}\right)\end{array}$ \\
\hline 7\% Acid & $8.87^{\mathrm{a}} \pm 0.081$ & $0.31^{\mathrm{a}} \pm 0.037$ & $0.10^{\mathrm{a}} \pm 0.018$ & $0.47^{\mathrm{a}} \pm 0.035$ \\
$7 \%$ Alkaline & $1,70^{\mathrm{b}} \pm 0.0030$ & $0.13^{\mathrm{bd}} \pm 0.016$ & $0.02^{\mathrm{b}} \pm 0.001$ & $0.59^{\mathrm{b}} \pm 0.053$ \\
$0.5 \%$ Acid & $14.48^{\mathrm{c}} \pm 0.42$ & $0.16^{\mathrm{b}} \pm 0.029$ & $0.01^{\mathrm{b}} \pm 0.010$ & $0.31^{\mathrm{c}} \pm 0.034$ \\
$0.5 \%$ Alkaline & $3.00^{\mathrm{d}} \pm 0.083$ & $0.04^{\mathrm{c}} \pm 0.008$ & $\mathrm{nd}$ & $0.69^{\mathrm{b}} \pm 0.013$ \\
Enzymatic & $12.80^{\mathrm{e}} \pm 0.74$ & $0.09^{\mathrm{d}} \pm 0.018$ & $\mathrm{nd}$ & $3.79^{\mathrm{d}} \pm 0.120$ \\
\hline
\end{tabular}

Note. $\mathrm{nd}=$ not detected $(\leq 0.001)$. Data are presented as mean \pm standard deviation $(\mathrm{SD})$ of at least four independent experiments. Means followed by the same letter in the same column do not differ significantly $(\mathrm{p}<0.05)$ according to the Tukey test. 
On the other hand, the enzymatic hydrolysate presented a high concentration of acetic acid (3.79 $\left.\mathrm{g} \mathrm{L}^{-1}\right)$; 5.5 times that of the second highest concentration $\left(0.69 \mathrm{~g} \mathrm{~L}^{-1}\right)$, observed in the dilute alkaline hydrolysate. Bazoti et al. (2017) performed the hydrolysis of steam-exploded sugarcane bagasse using Cellic CTec3 (Novozymes) enzymatic cocktail and obtained higher concentrations of inhibitors than those of the present study: $0.17 \mathrm{~g} \mathrm{~L}^{-11} \mathrm{HMF}, 0.36 \mathrm{~g} \mathrm{~L}^{-1}$ furfural, and $9.18 \mathrm{~g} \mathrm{~L}^{-1}$ acetic acid.

Aguilar et al. (2002) carried out a study with sugarcane bagasse using varied $\mathrm{H}_{2} \mathrm{SO}_{4}$ concentrations, temperatures, and treatment times. The authors analyzed the composition of the hydrolysate obtained under the optimum acid treatment conditions. When acid treatment was applied at $122{ }^{\circ} \mathrm{C}$, the concentrations of acetic acid and furfural were respectively 3.65 and $0.52 \mathrm{~g} \mathrm{~L}^{-1}$ using $2 \% \mathrm{H}_{2} \mathrm{SO}_{4}, 4.06$ and $1.06 \mathrm{~g} \mathrm{~L}^{-1}$ using $4 \% \mathrm{H}_{2} \mathrm{SO}_{4}$, and 4.53 and $1.21 \mathrm{~g}$ $\mathrm{L}^{-1}$ using $6 \% \mathrm{H}_{2} \mathrm{SO}_{4}$. These results are higher than those presented in Table 1, except for the concentration of acetic acid at $2 \% \mathrm{H}_{2} \mathrm{SO}_{4}\left(3.65 \mathrm{~g} \mathrm{~L}^{-1}\right)$, which was similar to that obtained for the enzymatic hydrolysate of the present study $\left(3.79 \mathrm{~g} \mathrm{~L}^{-1}\right)$.

Martín et al. (2002) also reported that HMF and furfural (in addition to formic acid, levulinic acid, and phenolic compounds) cause greater inhibitory effect in S. cerevisiae than acetic acid. The authors pretreated sugarcane bagasse by steam explosion using three strategies: using no impregnating agents, using sulfur dioxide $\left(1.1 \% \mathrm{SO}_{2}\right)$, or using sulfuric acid $\left(1 \% \mathrm{H}_{2} \mathrm{SO}_{4}\right)$ as impregnating agent. Then, the bagasse was submitted to enzymatic hydrolysis with a mixture of cellulases and $\beta$-glycosidases. To evaluate the fermentability of the hydrolysates, the authors cultivated $S$. cerevisiae (TMB 3001) in each hydrolysate for $48 \mathrm{~h}$ and observed that there was no difference between the fermentability of hydrolysates pretreated with no impregnating agent and those of hydrolysates pretreated with sulfur dioxide. On the other hand, no yeast growth was observed in the $\mathrm{H}_{2} \mathrm{SO}_{4}$ hydrolysate, which had the highest concentrations of HMF and furfural but an acetic acid concentration similar to those of the other hydrolysates. The authors concluded that acetic acid unlikely played a decisive role in lowering fermentability (Martín et al., 2002).

\subsection{Fermentative Performance}

After fermentation was complete, strains were evaluated for process parameters, such as biomass yield on substrate (Table 2), ethanol yield on substrate (Table 3), and ethanol productivity (Table 4). Although enzymatic treatment resulted in the highest acetic acid concentration, its biomass yield $\left(\mathrm{Y}_{\mathrm{X} / \mathrm{S}}\right)$, ethanol yield $\left(\mathrm{Y}_{\mathrm{P} / \mathrm{S}}\right)$, and ethanol productivity $\left(\mathrm{P}_{\mathrm{P}}\right)$ were not significantly different from those obtained by dilute acid $(0.5 \%)$ or dilute alkaline $(0.5 \%)$ treatments for practically all strains. The highest ethanol yield, in absolute values, was achieved using the FT858 strain on the enzymatic hydrolysate, which corresponded to $92 \%$ of the theoretical ethanol yield $\left(0.51 \mathrm{~g}\right.$ ethanol $\mathrm{g}^{-1}$ glucose $)$. The lowest yield was obtained with the SM strain using concentrated acid hydrolysate, corresponding to $8.4 \%$ of the theoretical yield.

Pereira et al. (2014) studied several $S$. cerevisiae strains, including PE-2 and CAT-1, cultivated in Eucalyptus globulus wood chip hydrolysate supplemented with $114 \mathrm{~g} \mathrm{~L}^{-1}$ glucose. In this study, PE-2 (94\%) and CAT-1 (92\%) ethanol yields were higher than those 
obtained in the present study ( $90 \%$ and $86 \%$, respectively, on enzymatic hydrolysate). On the other hand, Pereira et al. (2014) obtained lower ethanol yields for these strains $\left(0.78 \mathrm{~g} \mathrm{~L}^{-1} \mathrm{~h}^{-1}\right.$ for PE-2 and $0.49 \mathrm{~g} \mathrm{~L}^{-1} \mathrm{~h}^{-1}$ for CAT-1) than those of the present study (Table 4) when compared with the fermentation of enzymatic, $0.5 \%$ acid, and $0.5 \%$ alkaline hydrolysates.

In a study by Wanderley et al. (2013), the industrial S. cerevisiae strain UFPEDA 1238 was cultivated in sugarcane bagasse hydrolysate pretreated by steam explosion and enzymatic hydrolysis. Fermentation was carried out at $34{ }^{\circ} \mathrm{C}$ for different times, without agitation and without carbon source supplementation. The cultures analyzed after $48 \mathrm{~h}$ of fermentation presented higher biomass yield than those of the present work, with the exception of fermentations using concentrated alkaline hydrolysate. On the other hand, ethanol yields obtained by Wanderley et al. (2013) were lower than those obtained in the present study with dilute acid, dilute alkaline, and enzymatic hydrolysates, resulting in $46.47 \%$ of the theoretical ethanol yield.

Table 2. Biomass yield on substrate $\left(\mathrm{Y}_{\mathrm{X} / \mathrm{S}}, \mathrm{g} \mathrm{g}^{-1}\right)$ of fermentations of six industrial strains of $S$. cerevisiae using as substrate different sugarcane bagasse hydrolysates supplemented with 150 $\mathrm{g} \mathrm{L}^{-1}$ glucose and treated for $48 \mathrm{~h}$ at $30^{\circ} \mathrm{C}$ and $150 \mathrm{rpm}$

\begin{tabular}{llllll}
\hline & $7 \%$ & $7 \%$ & $0.5 \%$ & $0.5 \%$ & \\
Strain & $\begin{array}{l}\text { Acid } \\
\text { Hydrolysis }\end{array}$ & $\begin{array}{l}\text { Alkaline } \\
\text { Hydrolysis }\end{array}$ & $\begin{array}{llll}\text { Acid Hydrolysis } \\
\text { Alkaline } \\
\text { Hydrolysis }\end{array}$ & $\begin{array}{l}\text { Enzymatic } \\
\text { Hydrolysis }\end{array}$ \\
\hline CAT-1 & nq & $0.11^{\mathrm{a}, \mathrm{A}} \pm 0.035$ & $0.027^{\mathrm{a}, \mathrm{B}} \pm 0.0046$ & $0.012^{\mathrm{a}, \mathrm{B}} \pm 0.012$ & $0.022^{\mathrm{a}, \mathrm{B}} \pm 0.0013$ \\
PE-2 & nq & $0.10^{\mathrm{a}, \mathrm{A}} \pm 0.0061$ & $0.024^{\mathrm{a}, \mathrm{B}} \pm 0.0015$ & $0.0074^{\mathrm{a}, \mathrm{C}} \pm 0.0016$ & $0.019^{\mathrm{a}, \mathrm{BC}} \pm 0.0040$ \\
FT858 & nq & $0.076^{\mathrm{a}, \mathrm{A}} \pm 0.0029$ & $0.029^{\mathrm{a}, \mathrm{B}} \pm 0.0090$ & $0.013^{\mathrm{a}, \mathrm{B}} \pm 0.0079$ & $0.022^{\mathrm{a}, \mathrm{B}} \pm 0.0017$ \\
SM & nq & $0.14^{\mathrm{a}, \mathrm{A}} \pm 0.057$ & $0.023^{\mathrm{a}, \mathrm{B}} \pm 0.00061$ & $0.021^{\mathrm{a}, \mathrm{B}} \pm 0.0025$ & $0.015^{\mathrm{a}, \mathrm{B}} \pm 0.0014$ \\
SA-1 & nq & $0.11^{\mathrm{a}, \mathrm{A}} \pm 0.022$ & $0.023^{\mathrm{a}, \mathrm{B}} \pm 0.0037$ & $0.027^{\mathrm{a}, \mathrm{B}} \pm 0.0061$ & $0.019^{\mathrm{a}, \mathrm{B}} \pm 0.0022$ \\
NAD & nq & $0.19^{\mathrm{a}, \mathrm{A}} \pm 0.043$ & $0.026^{\mathrm{a}, \mathrm{B}} \pm 0.0041$ & $0.030^{\mathrm{a}, \mathrm{B}} \pm 0.00018$ & $0.020^{\mathrm{a}, \mathrm{B}} \pm 0.00085$ \\
\hline
\end{tabular}

Note. nq - not quantified. Data are presented as mean \pm standard deviation (SD) of two independent experiments. Means followed by the same letter do not differ significantly $(\mathrm{p}<$ 0.05 ) according to the Tukey test. Lowercase letters indicate comparisons between strains for the same hydrolysis treatment, and capital letters indicate comparisons between hydrolysis treatments for the same strain.

Andrade et al. (2013) analyzed the growth of SA-1 in sugarcane bagasse pretreated with hydrogen peroxide, followed by enzymatic hydrolysis, and supplementation with molasses to reach a final sugar concentration of $130 \mathrm{~g} \mathrm{~L}^{-1}$. The strain was cultivated in $1 \mathrm{~L}$ bioreactors at $30-38{ }^{\circ} \mathrm{C}$. Ethanol yields were $0.408-0.465 \mathrm{~g} \mathrm{~g}^{-1}$ and biomass yields were $0.023-0.026 \mathrm{~g} \mathrm{~g}^{-1}$. 
Table 3. Ethanol yield on substrate $\left(\mathrm{Y}_{\mathrm{P} / \mathrm{S}}, \mathrm{g} \mathrm{g}^{-1}\right)$ of six industrial strains of $S$. cerevisiae using as substrate different sugarcane bagasse hydrolysates supplemented with $150 \mathrm{~g} \mathrm{~L}^{-1}$ glucose and treated for $48 \mathrm{~h}$ at $30^{\circ} \mathrm{C}$ and $150 \mathrm{rpm}$

\begin{tabular}{llllll}
\hline \multirow{2}{*}{ Strain } & $7 \%$ & $7 \%$ & $0.5 \%$ & $0.5 \%$ & \\
& Acid Hydrolysis & $\begin{array}{l}\text { Alkaline } \\
\text { Hydrolysis }\end{array}$ & $\begin{array}{l}\text { Acid } \\
\text { Hydrolysis }\end{array}$ & $\begin{array}{l}\text { Alkaline } \\
\text { Hydrolysis }\end{array}$ & $\begin{array}{l}\text { Enzymatic } \\
\text { Hydrolysis }\end{array}$ \\
\hline CAT-1 & $0.047^{\mathrm{a}, \mathrm{A}} \pm 0.0037$ & $0.065^{\mathrm{a}, \mathrm{A}} \pm 0.024$ & $0.37^{\mathrm{a}, \mathrm{B}} \pm 0.017$ & $0.42^{\mathrm{a}, \mathrm{B}} \pm 0.042$ & $0.44^{\mathrm{a}, \mathrm{B}} \pm 0.017$ \\
PE-2 & $0.045^{\mathrm{a}, \mathrm{A}} \pm 0.0015$ & $0.056^{\mathrm{a}, \mathrm{A}} \pm 0.0012$ & $0.39^{\mathrm{a}, \mathrm{B}} \pm 0.030$ & $0.39^{\mathrm{a}, \mathrm{B}} \pm 0.023$ & $0.46^{\mathrm{a}, \mathrm{B}} \pm 0.13$ \\
FT858 & $0.057^{\mathrm{ab}, \mathrm{A}} \pm 0.0032$ & $0.059^{\mathrm{a}, \mathrm{A}} \pm 0.011$ & $0.40^{\mathrm{a}, \mathrm{B}} \pm 0.014$ & $0.37^{\mathrm{a}, \mathrm{B}} \pm 0.015$ & $0.47^{\mathrm{a}, \mathrm{B}} \pm 0.0096$ \\
SM & $0.043^{\mathrm{a}, \mathrm{A}} \pm 0.0069$ & $0.087^{\mathrm{a}, \mathrm{A}} \pm 0.034$ & $0.35^{\mathrm{a}, \mathrm{B}} \pm 0.0042$ & $0.43^{\mathrm{a}, \mathrm{C}} \pm 0.012$ & $0.44^{\mathrm{a}, \mathrm{C}} \pm 0.022$ \\
SA-1 & $0.076^{\mathrm{b}, \mathrm{A}} \pm 0.012$ & $0.082^{\mathrm{a}, \mathrm{A}} \pm 0.051$ & $0.34^{\mathrm{a}, \mathrm{B}} \pm 0.042$ & $0.45^{\mathrm{a}, \mathrm{B}} \pm 0.012$ & $0.43^{\mathrm{a}, \mathrm{B}} \pm 0.023$ \\
NAD & $0.050^{\mathrm{ab}, \mathrm{A}} \pm 0.0071$ & $0.072^{\mathrm{a}, \mathrm{A}} \pm 0.018$ & $0.38^{\mathrm{a}, \mathrm{B}} \pm 0.028$ & $0.43^{\mathrm{a}, \mathrm{BC}} \pm 0.022$ & $0.46^{\mathrm{a}, \mathrm{C}} \pm 0.0042$ \\
\hline
\end{tabular}

Note. Data are presented as mean \pm standard deviation (SD) of two independent experiments. Means followed by the same letter do not differ significantly $(p<0.05)$ according to the Tukey test. Lowercase letters indicate comparisons between strains for the same hydrolysis treatment, and capital letters indicate comparisons between hydrolysis treatments for the same strain.

Concentrated alkaline treatment resulted in the highest biomass yields ( $\mathrm{Y}_{\mathrm{X} / \mathrm{S}}$, Table 2), which were significantly higher than those produced by other treatments. However, it had one of the lowest ethanol yields ( $\mathrm{Y}_{\mathrm{P} / \mathrm{S}}$, Table 3), having no significant difference only from the results of the concentrated acid treatment. Figure 1 shows the size of the inoculum used to initiate fermentation, the biomass production, and the residual glucose concentrations at the end of fermentation (48 h) for $S$. cerevisiae SA-1; the results are representative of those of the other strains. In Figure 1, it is possible to observe that the high biomass yield $\left(\mathrm{Y}_{\mathrm{X} / \mathrm{S}}\right)$ generated from the concentrated alkaline hydrolysate was due to the large size of the inoculum. On the other hand, the high cell concentration was not able to produce ethanol because of the low consumption of glucose in the culture medium (the residual concentration of this carbon source was $99.8 \mathrm{~g} \mathrm{~L}^{-1}$ ). Thus, the ethanol content detected in the concentrated alkaline hydrolysate at the end of fermentation may be a residual product from the inoculation step; the same may apply to the ethanol content detected in concentrated acid hydrolysate. Thus, the results of this study show that, as in other studies, the size of the inoculum influenced ethanol production by $S$. cerevisiae (Turhan et al., 2010) as did the concentration of inhibitors in the culture medium (Boyer et al., 1992; Pereira et al., 2014; Li et al., 2017). 
Table 4. Ethanol productivity $\left(\mathrm{PP}, \mathrm{g} \mathrm{L}^{-1} \mathrm{~h}^{-1}\right)$ of six industrial strains of $S$. cerevisiae using as substrate different sugarcane bagasse hydrolysates supplemented with $150 \mathrm{~g} \mathrm{~L}^{-1}$ glucose and treated for $48 \mathrm{~h}$ at $30^{\circ} \mathrm{C}$ and $150 \mathrm{rpm}$

\begin{tabular}{llllll}
\hline \multirow{2}{*}{ Strain } & $7 \%$ & $7 \%$ & $0.5 \%$ & $0.5 \%$ & Enzymatic \\
& Acid & Alkaline & Acid & Alkaline & Hydrolysis \\
\cline { 3 - 5 } & Hydrolysis & Hydrolysis & Hydrolysis & Hydrolysis & \\
\hline CAT-1 & $0.044^{\mathrm{a}, \mathrm{A}} \pm 0.0052$ & $0.048^{\mathrm{a}, \mathrm{A}} \pm 0.00059$ & $0.83^{\mathrm{ab}, \mathrm{B}} \pm 0.17$ & $1.23^{\mathrm{a}, \mathrm{C}} \pm 0.12$ & $1.19^{\mathrm{a}, \mathrm{BC}} \pm 0.024$ \\
PE-2 & $0.040^{\mathrm{a}, \mathrm{A}} \pm 0.0062$ & $0.043^{\mathrm{ab}, \mathrm{A}} \pm 0.0013$ & $0.83^{\mathrm{ab}, \mathrm{B}} \pm 0.024$ & $1.12^{\mathrm{a}, \mathrm{BC}} \pm 0.072$ & $1.24^{\mathrm{a}, \mathrm{C}} \pm 0.15$ \\
FT858 & $0.046^{\mathrm{a}, \mathrm{A}} \pm 0.0031$ & $0.042^{\mathrm{ab}, \mathrm{A}} \pm 0.0031$ & $0.66^{\mathrm{b}, \mathrm{B}} \pm 0.011$ & $1.08^{\mathrm{a}, \mathrm{C}} \pm 0.032$ & $0.98^{\mathrm{a}, \mathrm{C}} \pm 0.052$ \\
SM & $0.037^{\mathrm{a}, \mathrm{A}} \pm 0.0021$ & $0.044^{\mathrm{ab}, \mathrm{A}} \pm 0.00088$ & $0.94^{\mathrm{a}, \mathrm{B}} \pm 0.016$ & $1.09^{\mathrm{a}, \mathrm{C}} \pm 0.018$ & $1.13^{\mathrm{a}, \mathrm{C}} \pm 0.038$ \\
SA-1 & $0.050^{\mathrm{a}, \mathrm{A}} \pm 0.0024$ & $0.045^{\mathrm{ab}, \mathrm{A}} \pm 0.00029$ & $0.79^{\mathrm{ab}, \mathrm{B}} \pm 0.024$ & $1.11^{\mathrm{a}, \mathrm{C}} \pm 0.032$ & $1.08^{\mathrm{a}, \mathrm{C}} \pm 0.090$ \\
NAD & $0.041^{\mathrm{a}, \mathrm{A}} \pm 0.0063$ & $0.040^{\mathrm{b}, \mathrm{A}} \pm 0.0021$ & $0.79^{\mathrm{ab}, \mathrm{B}} \pm 0.0024$ & $1.11^{\mathrm{a}, \mathrm{C}} \pm 0.019$ & $1.18^{\mathrm{a}, \mathrm{D}} \pm 0.0018$ \\
\hline
\end{tabular}

Note. Data are presented as mean \pm standard deviation (SD) of two independent experiments. Means followed by the same letter do not differ significantly $(\mathrm{p}<0.05)$ according to the Tukey test. Lowercase letters indicate comparisons between strains for the same hydrolysis treatment, and capital letters indicate comparisons between hydrolysis treatments for the same strain.

It was possible to observe that the studied strains were not able to grow as readily in concentrated acid hydrolysate as in other hydrolysates. This was due to the high concentrations of inhibitors in the medium, as the concentrated acid hydrolysate presented the highest HMF and furfural concentrations (Table 1). However, S. cerevisiae strains cultured in $7 \%$ acid hydrolysate were able to produce small amounts of ethanol (Table 3 ). In addition, the $\mathrm{Y}_{\mathrm{P} / \mathrm{S}}$ of each strain in 7\% acid hydrolysate was not significantly different from that obtained in 7\% alkaline hydrolysate. Of the six strains, it can be observed that three strains (FT858, SA-1, and NAD) produced significantly higher amounts of ethanol, indicating that these strains may be more robust than the others. Therefore, these three strains were evaluated for their tolerance to fermentation inhibitors. 


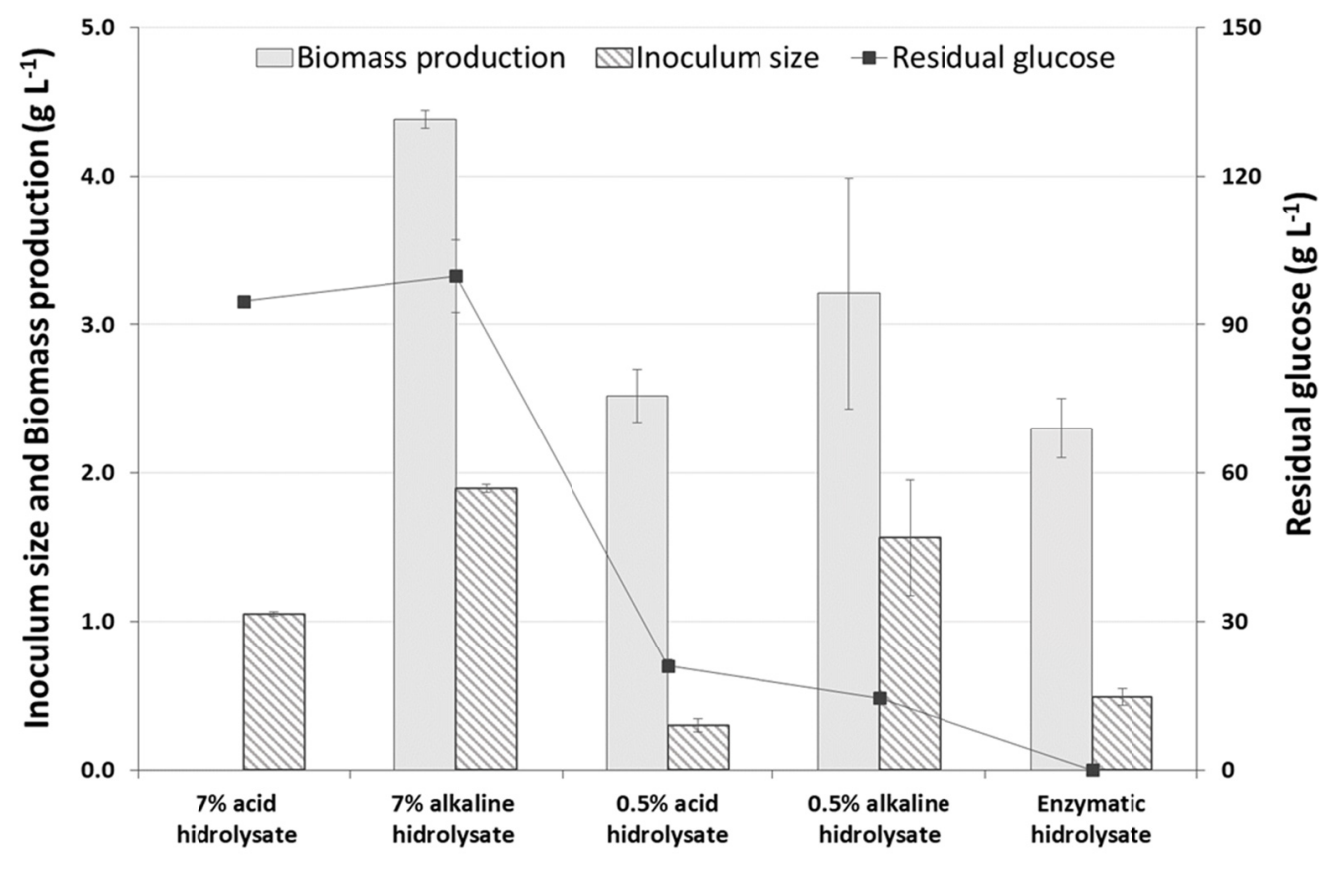

Figure 1. Biomass production and residual glucose concentration by $S$. cerevisiae SA-1 using different sugarcane bagasse hydrolysates as substrates, supplemented with $150 \mathrm{~g} \mathrm{~L}^{-1}$ glucose and treated for $48 \mathrm{~h}$ at $40{ }^{\circ} \mathrm{C}$ and $150 \mathrm{rpm}$

\subsection{Tolerance to Fermentation Inhibitors}

Many studies have demonstrated the inhibitory effect of HMF, furfural, and acetic acid on $S$. cerevisiae cell growth and ethanol production (Boyer et al., 1992; Pereira et al., 2014; Li et al., 2017). In order to evaluate the robustness of the strains that were able to produce ethanol (FT858, SA-1, and NAD), even if at low concentrations, from 7\% acid hydrolysate, a growth test was performed using HMF, furfural, and acetic acid, separately, at different concentrations.

Figure 2 shows the relative growth ( $\mathrm{RG} \%$, Equation 4$)$ of the three strains in the presence of inhibitors in relation to their growth in the absence of inhibitors. S. cerevisiae SA-1 had the best $\mathrm{RG} \%$ for three of the six conditions under which cells were able to grow (1.0 furfural, $4.0 \mathrm{~g} \mathrm{~L}^{-1}$ furfural, and $1.0 \mathrm{~g} \mathrm{~L}^{-1} \mathrm{HMF}$ ), which indicates that it is more robust than FT858 and NAD. Although SA-1 had significantly different RG\% values from those of FT858 under the other three conditions, its $\mathrm{RG} \%$ was not greatly lower than that of FT858. Under cultivation conditions containing 6.0 or $12.0 \mathrm{~g} \mathrm{~L}^{-1}$ acetic acid, no cell growth was observed in $24 \mathrm{~h}$ for the three strains. On the other hand, in $3.0 \mathrm{~g} \mathrm{~L}^{-1}$ acetic acid (represented by ${ }^{*}$ ), the three strains were able to grow after $20 \mathrm{~h}$ of cultivation but were unable to reach the stationary phase in $24 \mathrm{~h}$ (results not shown); consequently, it was not possible to calculate their RG\%. 


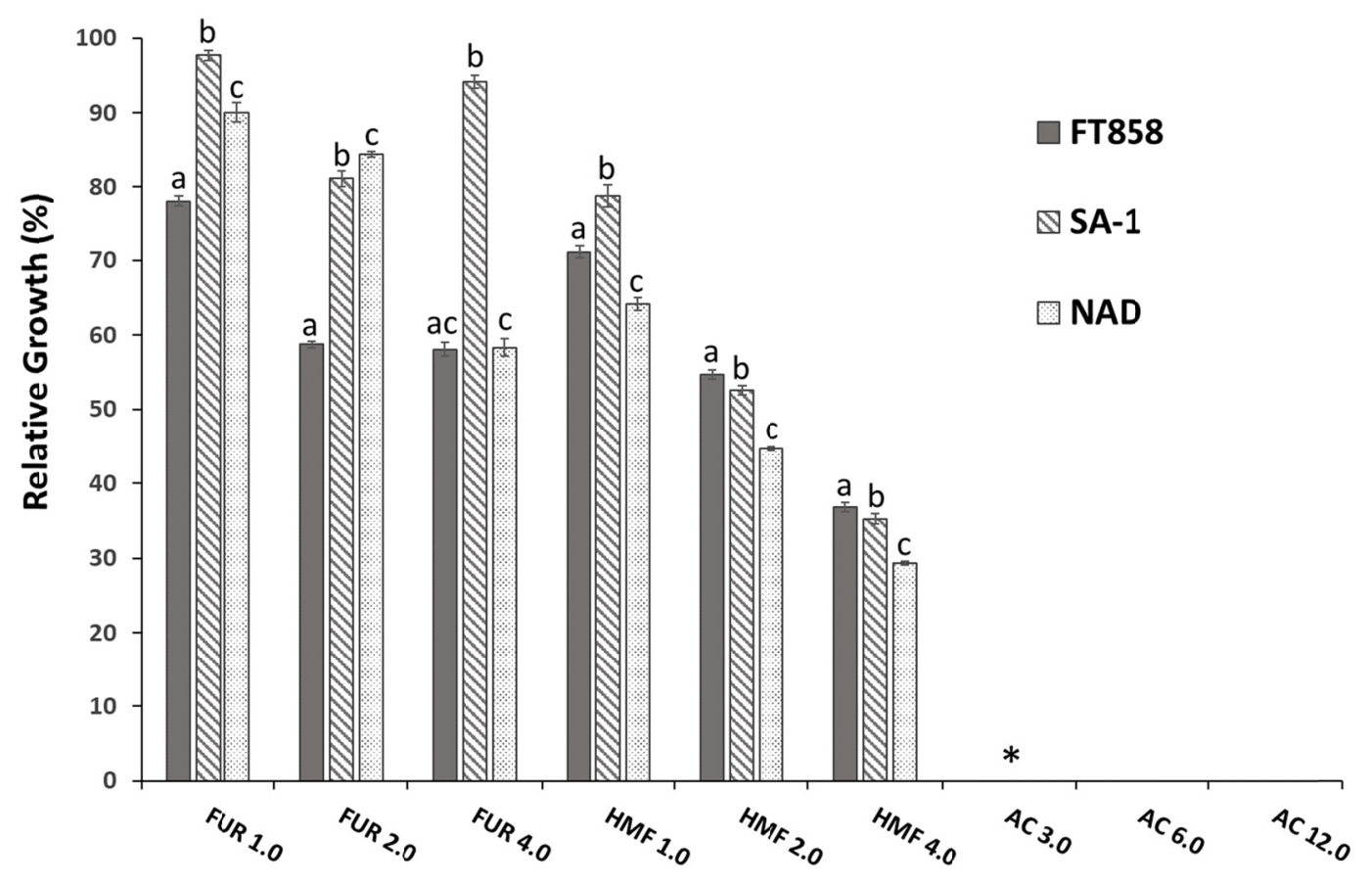

Figure 2. Tolerance of $S$. cerevisiae FT858, SA-1, and NAD to the fermentation inhibitors hydroxymethylfurfural (HMF), furfural (FUR), and acetic acid (AC) at different concentrations $\left(\mathrm{g} \mathrm{L}^{-1}\right)$. $* \mathrm{RG} \%$ not calculated. Data represent the means of three independent experiments. Columns with the same letter do not differ significantly $(p<0.05)$ between strains for the same inhibitor according to the Tukey test

It is also possible to observe in Figure 2 that the cultures containing HMF had a lower RG\% than cultures containing furfural at the same concentration, demonstrating that the inhibitory effect of HMF is greater than that of furfural. Li et al. (2017) reported that inhibitory compounds present in lignocellulosic materials have negative effects of different intensities on the growth of microorganisms. In fermentations using glucose as carbon source, HMF had a greater inhibitory effect on cell growth than furfural.

A study by Boyer et al. (1992) also demonstrated the negative effects of furfural on cell growth, ethanol production, and glucose uptake. The authors observed an increase in the lag phase of $S$. cerevisiae ATCC 24860 when grown at $30{ }^{\circ} \mathrm{C}$ in culture medium containing glucose $(10 \%)$, yeast extract $(3 \%)$, and different concentrations of furfural $\left(0-2.0 \mathrm{~g} \mathrm{~L}^{-1}\right)$ and initial inoculum (0.1-9.0 $\left.\mathrm{g} \mathrm{L}^{-1}\right)$. Li et al. (2017) studied the inhibitory effect of eight different fermentation inhibitors, among which were furfural, HMF, and acetic acid, in a modified lineage of $S$. cerevisiae. The authors observed that HMF and furfural had a stronger negative effect on yeast growth in comparison with acetic acid.

\section{Conclusion}

The results presented show that for all parameters there were no significant differences 
between strains when using the same hydrolysate. On the other hand, when parameters were analyzed using a single strain but different hydrolysates, significant differences were observed between the results. These findings demonstrate that the six industrial strains of $S$. cerevisiae evaluated in this study are physiologically similar in terms of glucose consumption and ethanol production when grown in a given hydrolysate. FT858, SA-1, and NAD were able to produce small amounts of ethanol in concentrated acid (7\%), a severe condition with greater concentrations of furanosidic inhibitors. When evaluated for tolerance to fermentation inhibitors (HMF, furfural, and acetic acid), SA-1 showed greater robustness than other strains and, therefore, its use is indicated for the fermentation of lignocellulosic materials.

\section{References}

Aguilar, R et al. (2002). Kinetic study of the acid hydrolysis of sugar cane bagasse. $J$ Food Eng, 55, 309-318. https://doi.org/10.1016/S0260-8774(02)00106-1

Almeida, J. R. M. et al. (2007). Increased tolerance and conversion of inhibitors in lignocellulosic hydrolisates by Saccharomyces cerevisiae. J Chem Technol Biothecnol, 82, 340-349. https://doi.org/10.1002/jctb.1676

Almeida, J. R. M. et al. (2009). Screening of Saccharomyces cerevisiae strains with respect to anaerobic growth in non-detoxified lignocellulose hydrolysate. Bioresour Technol, 100, 3674-3677. https://doi.org/10.1016/j.biortech.2009.02.057

Andrade, R. R. et al. (2013). Kinetics of ethanol production from sugarcane bagasse enzymatic hydrolysate concentrated with molasses under cell recycle. Bioresour Technol, 130, 351-359. https://doi.org/10.1016/j.biortech.2012.12.045

Balat, M. (2011). Production of bioethanol from lignocellulosic materials via the biochemical pathway: a review. Energy Conv Manag, 52, 858-875. https://doi.org/10.1016/j.enconman.2010.08.013

Bastos, V. D. (2007). Etanol, Alcoolquímica e Biorrefinarias. Retrieved from https://web.bndes.gov.br/bib/jspui/bitstream/1408/2527/1/BS\%2025\%20Etanol\%2C\%20Alco olqu $\%$ C3\%ADmica $\% 20 \mathrm{e} \% 20$ Biorrefinarias_P.pdf

Bazoti, S. F. et al. (2017). Second-generation ethanol from non-detoxified sugarcane hydrolysate by a rotting wood isolated yeast strain. Bioresour Technol, 244, 582-587. https://doi.org/10.1016/j.biortech.2017.08.007

Boyer, L. J. et al. (1992). The effects of furfural on ethanol production by Saccharomyces cerevisiae in batch culture. Biomass Bioenergy, 3, 41-48. https://doi.org/10.1016/0961-9534(92)90018-L

Cardona, C. A. et al. (2010). Production of bioethanol from sugarcane bagasse: Status and $\begin{array}{llll}\text { perspectives. } \quad \text { Bioresour } & \text { Technol, } & \text { 4754-4766. }\end{array}$ https://doi.org/10.1016/j.biortech.2009.10.097

Charoenchai, C. et al. (1998). Effects of Temperature, pH, and Sugar Concentration on the Growth Rates and Cell Biomass of Wine Yeasts. Am J Enol Vitic, 49, 283-288 
Cheng, K. K. et al. (2008). Sugarcane bagasse hemicellulose hydrolysate for ethanol production by acid recovery process. Biochem Eng J, 38, 105-109. https://doi.org/10.1016/j.bej.2007.07.012

Della-Bianca, B. E. et al. (2013). What do we know about the yeast strains from the brazilian fuel ethanol industry? Appl Microbial Biotechnol, 97, 979-991. https://doi.org/10.1007/s00253-012-4631-x

Landaeta, R. et al. (2013). Adaptation of a flocculent Saccharomyces cerevisiae strain to lignocellulosic inhibitors by cell recycle batch fermentation. Appl Energy 102, 124-130. https://doi.org/10.1016/j.apenergy.2012.06.048

Li, Y. G. et al. (2017). Inhibitor tolerance of a recombinant flocculating industrial Saccharomyces cerevisiae strain during glucose and xylose co-fermentation. Brazilian J Microbiol ,48, 791-800. https://dx.doi.org/10.1016/j.bjm.2016.11.011

Martín, C. et al. (2002). Comparison of the Fermentability of Enzymatic Hydrolyzates of Sugarcane Bagasse Pretreated by Steam Explosion Using Different Impregnating Agents. Appl Biochem Biotechnol, 98, 699-716. https://doi.org/10.1385/ABAB:98-100:1-9:699

Martín, C. et al. (2006). Adaptation of a recombinant xylose-utlizing Saccharomyces cerevisiae strain to a sugarcane bagasse hydrolysate with high content of fermentation inhibitors. Bioresour Technol, 9, 1763-1773. https://doi.org/10.1016/j.biortech.2006.07.021

Miller, G. L. (1959). Use of dinitrosalicylic acid reagent for determination of reducing sugar. Anal Chem, 31, 426-428. https://doi.org/10.1021/ac60147a030

Mussatto, S. I. et al. (2010). Technological trends, global market, and challenges of bioethanol production. Biotechnol Adv, 28, 817-830. https://doi.org/10.1016/j.biotechadv. 2010.07.001

Pattra, S. et al. (2008). Bio-hydrogen production from the fermentation of sugarcane bagasse hydrolysate by Clostridium butyricum. International J Hydrogen Energy, 33, 5256-5265. https://doi.org/10.1016/j.ijhydene.2008.05.008

Peng, F. et al. (2009). Comparative study of hemicelluloses obtained by graded ethanol precipitation from sugarcane bagasse. J Agric Food Chem, 57, 6305-6317. https://doi.org/10.1021/jf900986b

Pereira, F. B. et al. (2014). Industrial robust yeast isolates with great potential for fermentation of lignocellulosic biomass. Bioresour Technol, 161, 192-199. https://doi.org/10.1016/j.biortech.2014.03.043

Turhan, I. et al. (2010). Ethanol production from carob extract by using Saccharomyces cerevisiae. Bioresour Technol, 101, 5290-5296. https://doi.org/10.1016/j.biortech.2010. 01.146

Verduyn, C. et al. (1992). Effect of benzoic acid on metabolic fluxes in yeasts: A continuousculture study on the regulation of respiration and alcoholic fermentation. Yeast, 8, 501-517. 
https://doi.org/10.1002/yea.320080703

Wanderley, M. C. A. et al. (2013). Increase in ethanol production from sugarcane bagasse based on combined pretreatments and fed-batch enzymatic hydrolysis. Bioresour Technol, 128, 448-453. https://doi.org/10.1016/j.biortech.2012.10.131

Yang, S. et al. (2010). Paradigm for industrial strain improvement identifies sodium acetate tolerance loci in Z. mobilis and S. cerevisiae. Proc Natl Acad Sci 107, 10395-10400. https://doi.org/10.1073/pnas.0914506107

\section{Copyright Disclaimer}

Copyright reserved by the author(s).

This article is an open-access article distributed under the terms and conditions of the Creative Commons Attribution license (http://creativecommons.org/licenses/by/3.0/). 